\title{
WATER CONSUMPTION WHEN EXPOSED TO SUN AND SHADE FOR NATIVE GOATS IN THE SEMIARID OF THE STATE OF PARAIBA, BRAZIL ${ }^{1}$
}

\author{
DERMEVAL A. FURTADO ${ }^{2}$, JACKSON R. DE S. LEITE ${ }^{3}$, \\ JOSE W. B. DO NASCIMENTO ${ }^{2}$, ANTONIO F. LEAL ${ }^{2}$, ANDREA S. SILVA ${ }^{4}$
}

\begin{abstract}
This work aimed to evaluate the preference and water consumption of native goats in the semiarid of Brazil. The water was freely supplied, in individual buckets, one exposed to the sun and the other in the shade. The experiment was realized using 18 animals of Moxotó, Graúna and Azul breeds, with average weight of $16,6 \pm 2,4 \mathrm{~kg}$, kept in confinement in individual stalls equipped with feeders and drinkers, during the period from January to February of 2009. The water temperature was measured by sensors (thermocouples type $\mathrm{T}$ - copper/constantan), which were coupled to a system of data acquisition. It was observed that the average water temperature exposed to the sun was $29.02{ }^{\circ} \mathrm{C}$, and $23.85{ }^{\circ} \mathrm{C}$ in the shade. For all breeds there was a preference for the water exposed to the sun, corresponding to an average consumption of $64.71 \%$ of the total. Among the breeds, the greatest preference for water exposed to the sun was the Azul (71.18\%), followed by the Moxotó (65.95\%) and the Graúna (57.00\%). The animals consumed more water during the day, and the average water consumption was 1.15 grams day $^{-1}$, corresponding to $6.9 \%$ of body weight of the animals.
\end{abstract}

KEYWORDS: goats behavior, native breeds, water temperature.

\section{CONSUMO DE ÁGUA QUANDO EXPOSTA AO SOL E À SOMBRA POR CAPRINOS NATIVOS NO SEMIÁRIDO PARAIBANO}

RESUMO: O trabalho teve o objetivo de avaliar a preferência e o consumo de água por caprinos nativos no semiárido brasileiro, fornecida à vontade, em baldes individuais, sendo um exposto ao sol e outro à sombra. $\mathrm{O}$ experimento foi realizado, utilizado-se de 18 animais das raça Moxotó, Graúna e Azul, com peso vivo médio de $16,6 \pm 2,4 \mathrm{~kg}$, mantidos em confinamento, em baias individuais, providas de comedouro e bebedouro, durante o período de janeiro a março de 2009. A temperatura da água foi medida através de sensores (termopares tipo $\mathrm{T}$ - cobre/constantan), que estavam acoplados a um sistema de aquisição de dados. Observou-se que a temperatura média da água exposta ao sol foi de $29,02{ }^{\circ} \mathrm{C}$, e à sombra, de $23,85^{\circ} \mathrm{C}$. Para todas as raças, houve preferência pela água exposta ao sol, correspondendo a um consumo médio de $64,71 \%$ do total. Entre as raças, a maior preferência pela água exposta ao sol foi da Azul (71,18\%), seguida da Moxotó $(65,95 \%)$ e Graúna $(57,00 \%)$. Os animais consumiram mais água no período diurno, sendo o consumo médio de 1.150 gramas $\mathrm{dia}^{-1}$, correspondendo a $6,9 \%$ do peso vivo dos animais.

PALAVRAS-CHAVE: comportamento de caprinos, raças nativas, temperatura da água.

\footnotetext{
${ }^{1}$ Extraído da dissertação de mestrado do segundo autor.

${ }^{2}$ Zootecnista, Doutor em Recursos Naturais, prof. Doutor da Unidade Acadêmica de Engenharia Agrícola,UFCG, Campina Grande PB, dermeval@deag.ufcg.edu.br.

${ }^{3}$ Zootecnista, Mestre em Engenharia Agrícola.jrs_leite@ hotmail.com.

${ }^{2}$ Eng ${ }^{\circ}$ Agrícola, Doutor em Engenharia de Estruturas, Prof. Doutor da Unidade Acadêmica de Engenharia Agrícola, UFCG, Campina Grande-PB,wallace@deag.ufcg.edu.br.

${ }^{2}$ Eng $^{\mathrm{o}}$ Civil, Doutor em Engenharia de Materiais, Prof. Doutor do Departamento de Engenharia de Materiais da UFPB, João Pessoa -

PB, antoniofleal@gmail.com.

${ }^{4}$ Zootecnista, Mestre em Zootecnia, deazootec@yahoo.com.br.

Recebido pelo Conselho Editorial em: 19-4-2011
}

Aprovado pelo Conselho Editorial em: 5-9-2011 


\section{INTRODUCTION}

The herd of goats in the Northeast region is composed mostly of native breeds of animals and Without Racial Standard Defined (WRSD), with remarkable ruggedness, but low production of milk and meat, and with a little genetic variability, thus the creation of animals of breed standard, as the native goats, is an important component of intensive production, because it influences the rate of weight gain, the precocity and the feed conversion (MATTOS et al., 2006).

Among the native breeds of goats in the Brazilian northeast, there are the Moxotó, Graúna and Azul breeds, perfectly adapted to the local soil, climate and vegetation type of the semiarid region, where they are reared for the production of meat, skin and milk, and they are also very efficient in the water use (ROCHA et al., 2009; ARAÚJO et al., 2010).

Water is the nutrient required in the largest amounts by goats, and vital part of any biological system of life, participating in physiological processes such as digestion, transport, absorption, and regulating body temperature, as it has high specific heat, and it does not permit the increase of the body temperature, even when the animal performs muscular work (CALLE \& SÁNCHEZ, 1995). It is also the most abundant substance in living systems (NRC, 2007), and the percentage of water in the body of goats depends on the alimentation, the age of the animal and the amount of fat, protein and ash present in their bodies (ALVES et al., 2008; DIAS et al., 2008; ARAÚJO et al., 2010). Water requirements for goats vary with the seasons, air temperature, weight, stage of production, type and food intake (ABIOJA et al., 2010), and the animals at elevated temperatures increase water intake, and thus this must be offered to the animals on tropical climate in sufficient quantity and desirable quality (BRASIL et al., 2000; NRC, 2007), aiming to replace losses through perspiration and respiration, besides possible body cooling, through the water contact, colder than the body, with the mucous membranes of the digestive tract, and replace losses through urine, feces and in the milk production.

The highest water consumption occurs in the hottest times of day and when there are higher levels of supplementation, i.e., higher dry matter and protein intake (RIBEIRO et al., 2006; POMPEU et al., 2009). The amount of water intake and its frequency of ingestion vary with the chemical composition of food, climate, as well as the inherent characteristics of the animals. According to the NRC (2007), there is a correlation between the consumption of dry matter and water consumption, and for each kilo of dry matter consumed, the animal must ingest 2.87 liters of water. For MACARI \& FURLAN (2001), special care is needed during stress management, especially those associated with quality and water temperature, since the increase in consumption benefits the animals, to act as heat attenuator. CALLE \& SÁNCHEZ (1995) reported that water consumption decreases when its temperature is less than $6{ }^{\circ} \mathrm{C}$ and when it exceeds $36{ }^{\circ} \mathrm{C}$.

It is important for production systems to be aware of the eating habits of animals, so they can detect management, food or health problems through changes in behavioral patterns. According to RIBEIRO et al. (2006) and RIBEIRO et al. (2009), the feeding habits of goats is associated with their behavior, which is connected to a set of factors involving the nature and form of food, and organoleptic qualities and repulsive or toxic antinutritional substances, the animal itself, the climate that it is submitted, and the water consumption linked to its quantity and quality. Studies with preference, consumption and productivity of animals related to water are still scarce in Brazil and abroad (ARAÚJO et al., 2010). Therefore, this study was to evaluate the preference and consumption of water when exposed to sun and shade, for native goats in semiarid region.

\section{MATERIAL E METHODS}

The study was conducted at the Experimental Station for Research in Small Ruminants, belonging to the Center of Agrarian Sciences, of the Federal University of Paraíba, in São João do Cariri, located at coordinates $7^{\circ} 23^{\prime} 27^{\prime \prime}$ South Latitude and $36^{\circ} 31^{\prime} 58^{\prime \prime}$ West Longitude, in the semiarid Brazilian northeast. The climate is classified as Bsh (hot semiarid), according to the 
Köeppen climate classification, with average annual temperatures of $26^{\circ} \mathrm{C}$, annual rainfall of $395 \mathrm{~mm}$, with irregular distribution and relative humidity around 68\% (Bacia Escola/UFCG).

It was used 18 non-castrated goats of Azul, Graúna, and Moxotó breeds, with a mean age of five months and initial average weight of $15.93 \pm 1.7$. The animals were housed in three open sheds, covered with ceramic tiles, unpaved floor, oriented east-west, consisting of 10 individual stalls each, measuring an area of $3.75 \mathrm{~m}^{2}$ per stall, fitted with individual feeders and drinkers. The experiment lasted 97 days, the first 21 for the animals to adapt to experimental conditions and 76 for data collection.

The water supplied to the animals came from the supply system of the city of São João do Cariri, freely, and in each stall two buckets of water were placed, one exposed to the sun and the other in shade. Daily, 6,000 g of water, 3,000 g in each bucket, were provided, so that the animal could choose which type of water it would consume. In the next day, the amount of water that was left in each bucket was measured, resulting in consumption by difference. Consumption was measured three times per week on alternate days, always on sunny days. It was also verified daily rate of evaporation through the distribution of buckets located in sun and shade, so that in the next day it could be verified the amount of water lost by evaporation and, thus, to deduct the losses of the animals consumption.

The experimental diet (Tables 1 and 2), with $47 \%$ forage and 53\% concentrate, made up of forage palm, Buffel hay, corn grits, soybean meal and mineral supplement was formulated according to the recommendations of the NRC (2007) to attend the nutritional requirements of animals with $15 \mathrm{~kg}$ of body weight and to provide daily gains of 150 grams, and was given twice a day (at $8 \mathrm{am}$ and at $4 \mathrm{pm}$ ) in the form of complete mixing. The offer was adjusted daily to allow $20 \%$ surplus of which $10 \%$ were removed, which were placed in a freezer, along with samples of food offered. The determination of dry matter (DM) was performed according to the methodology proposed by AOAC (2005). The DM intake was calculated by means of the differences between the total quantity of DM contained in the diet offered and contained on the surplus collected. Water consumption in relation to dry matter intake was calculated from the formula quoted by NRC (2007) described below:

$$
\mathrm{WTI}=3,86 \mathrm{DMI}-0,99
$$

where, WTI is the water consumption (liters) and DMI is dry matter intake (kg).

The observations concerning the water consumption of goats were performed between 12 hours of the first day of harvest up to 12 hours of the next day, in visual form, by the method of instantaneous scanning, at intervals of five minutes, for four full periods of 24 hours, being recorded in pre-designed forms, the demand for water by animals, the number of times the animal was looking for the water fountain and drinking water. The air temperature (AT), relative humidity (RH) and water temperature in sun and shade were collected during 24 hours, every minute, sensors coupled to an electronic data acquisition (T-type thermocouples - copper/constantan). These data were transferred to computer for calculation of the mean temperatures for each hour.

TABLE 1. Chemical composition of the experimental diet ingredients based in dry matter.

\begin{tabular}{lccccccccc}
\hline \multicolumn{1}{c}{ Ingredients } & DM & OM & MM & CP & NDF & ADF & EE & TCHO & NFC \\
\hline Buffel hay & 86.46 & 87.67 & 12.33 & 5.10 & 72.40 & 48.30 & 1.20 & 81.37 & 8.97 \\
Forage palm & 9.80 & 89.12 & 10.88 & 3.10 & 28.90 & 20.40 & 1.25 & 84.77 & 55.87 \\
Mineral supplement & 97.10 & - & 86.08 & - & - & - & - & - & - \\
Soybean meal & 90.00 & 93.11 & 6.89 & 48.50 & 14.08 & 10.40 & 1.41 & 43.20 & 29.12 \\
Corn grits & 87.09 & 98.42 & 1.58 & 9.20 & 12.45 & 5.90 & 4.06 & 85.16 & 72.71 \\
\hline
\end{tabular}

DM - dry matter; OM - organic matter; MM - mineral matter; CP - crude protein; NDF - neutral detergent fiber; ADF - acid detergent fiber; EE - ether extract; TCHO - Total carbohydrates; NFC - non-fiber carbohydrate. 
TABLE 2. Ingredients participation and chemical composition in the experimental diet of dry matter.

\begin{tabular}{|c|c|}
\hline Ingredients & $(\%)$ \\
\hline Buffel hay & 35.00 \\
\hline Forage palm & 12.00 \\
\hline Mineral supplement ${ }^{1}$ & 1.00 \\
\hline Soybean meal & 13.00 \\
\hline Corn grits & 39.00 \\
\hline Bromatological composition (\%) & $(\%)$ \\
\hline Dry matter & 44.80 \\
\hline Organic matter & 92.01 \\
\hline Mineral matter & 7.99 \\
\hline Crude protein & 12.0 \\
\hline Metabolizable energy (Mcal) $^{2}$ & 2.32 \\
\hline Ether Extract & 1.77 \\
\hline Total carbohydrates & 78.19 \\
\hline Non-fiber carbohydrates & 42.69 \\
\hline Neutral detergent fiber & 35.50 \\
\hline Acid detergent fiber & 23.02 \\
\hline
\end{tabular}

${ }^{\mathrm{T}}$ Mineral supplement (nutrient/kg of supplement): vitamin A 135,000.00 U.I.; Vitamin D3 68,000.00 U.I.; vitamin E 450.00 U.I.; calcium $240 \mathrm{~g}$; phosphorus $71 \mathrm{~g}$; potassium $28,2 \mathrm{~g}$; sulfur $20 \mathrm{~g}$; magnesium $20 \mathrm{~g}$; copper $400 \mathrm{mg}$; cobalt $30 \mathrm{mg}$; chromium $10 \mathrm{mg}$; iron $2500 \mathrm{mg}$; iodine $40 \mathrm{mg}$; manganese $1350 \mathrm{mg}$; selenium $15 \mathrm{mg}$; zinc $1700 \mathrm{mg}$; maximum fluoride $710 \mathrm{mg}$; Solubility of Phosphorus (P) in Citric Acid at $2 \%$ (min.). ${ }^{2}$ Estimated through the total digestible nutrients (TDN)

Sensors to measure temperature and humidity were fixed at the mass center of the animals (0.6 m height). The sensors used to measure the water temperature (sun and shade) were placed in the buckets, with the same quantity of water offered to the animals and installed in an empty stall, close to the animals. Climatic data, water preference, and water and dry matter consumption were submitted to analysis of variance and, when necessary, to Tukey test ( $>>0.05)$, using the completely randomized design, using the Statistical Analysis System Institute (SAS, 2000).

\section{RESULTS AND DISCUSSION}

The mean values of temperature and relative humidity are presented in Table 3, where there is a significant difference $(\mathrm{P}<0.05)$ between the hours surveyed. About the AT, it was observed that at periods considered the hottest of the day, between $12 \mathrm{pm}$ and $3 \mathrm{pm}$, this was above the thermal comfort zone for goats, which according to BAÊTA \& SOUZA (2010), should be between 20 and $30{ }^{\circ} \mathrm{C}$, and at $3 \mathrm{pm}$ approached the upper critical temperature, $34{ }^{\circ} \mathrm{C}$.

TABLE 3. Means values of air temperature (AT) and relative air humidity (RH), at different times.

\begin{tabular}{lcccccccc}
\hline & \multicolumn{7}{c}{ Hours } \\
\hline & $6 \mathrm{am}$ & $9 \mathrm{am}$ & $12 \mathrm{pm}$ & $3 \mathrm{pm}$ & $6 \mathrm{pm}$ & $9 \mathrm{pm}$ & $12 \mathrm{am}$ & $3 \mathrm{am}$ \\
\hline AT $\left({ }^{\circ} \mathrm{C}\right)$ & $22.9 \mathrm{fg}$ & $26.9 \mathrm{~d}$ & $31.1 \mathrm{~b}$ & $33.1 \mathrm{a}$ & $28.2 \mathrm{c}$ & $24.0 \mathrm{e}$ & $23.2 \mathrm{ef}$ & $22.2 \mathrm{~g}$ \\
RH $(\%)$ & $89.8 \mathrm{a}$ & $55.2 \mathrm{e}$ & $40.9 \mathrm{~g}$ & $37.1 \mathrm{~h}$ & $51.9 \mathrm{f}$ & $64.4 \mathrm{~d}$ & $68.8 \mathrm{c}$ & $75.2 \mathrm{~b}$ \\
\hline
\end{tabular}

Means followed by the same letter in the row do not differ at $5 \%$ of probability by the Tukey test.

About the RH, from 3 am to 6 am, it was above the recommended, 50 to $70 \%$; at 9 am, $6 \mathrm{pm}$, $9 \mathrm{pm}$ and $12 \mathrm{am}$, it was within the range of thermal comfort; and at $12 \mathrm{pm}$ and $3 \mathrm{pm}$, it was below the recommended, characterizing a situation of thermal discomfort. Correlating the AT and RH, it is observed that in the period from $12 \mathrm{pm}$ to $3 \mathrm{pm}$, the animals were outside the thermal comfort zone, characterizing the environment as stressful. These values were similar to those found by FURTADO et al. (2008) and SILVA et al. (2010), who also reported high temperatures associated with low relative humidity during the day, in studies made with goats in Brazilian semiarid region. 
The mean water temperature in the sun was $29^{\circ} \mathrm{C}$ and $23.8^{\circ} \mathrm{C}$ in the shade, and water temperature in the sun was above the recommended value for several animal species (MACARI \& FURLAN, 2001), which should be below $24{ }^{\circ} \mathrm{C}$. Figure 1 shows the temperature of the water exposed to sun and shade during the periods of the day, which can be noted that the exposure to the sun, at $2 \mathrm{pm}$ to $4 \mathrm{pm}$, was higher than $38^{\circ} \mathrm{C}$, remaining above the recommendations from CALLE \& SÁNCHEZ (1995), which mentioned that the water consumption decreases with temperatures above $36{ }^{\circ} \mathrm{C}$. ARAÚJO et al. (2010) reported that the water temperature is an important factor, because if this is high, it may change the microbial population and, consequently, the fermentation in the rumen.

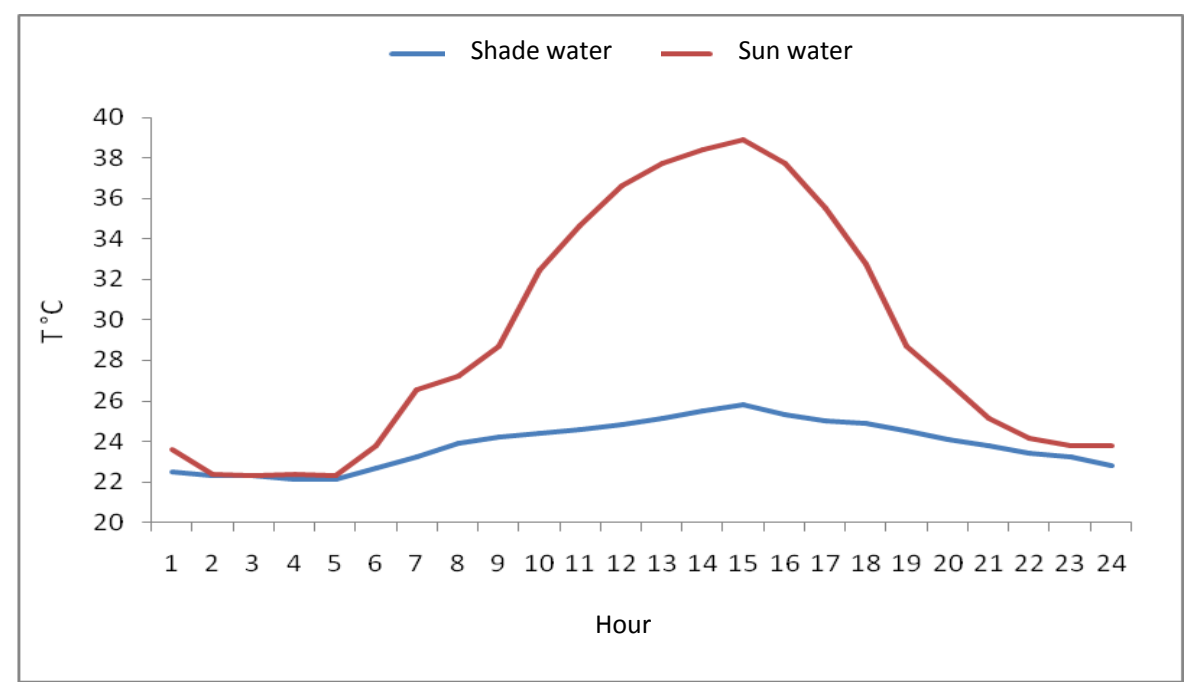

FIGURE 1. Water temperature $\left({ }^{\circ} \mathrm{C}\right)$ in the sun and in the shade during the day hours.

Analyzing the feeding behavior of goats (Table 4), it may observe that the animals sought the water drinker to consume water, on average, 2.83 times per day, which is consistent with the normal level of water intake for goats. It was also noted that increased demand for water was made by Moxotó, followed by the Azul goats, and the animals which visited the least the water fountains were the ones from the Graúna breed. This consumption was similar to that found by BARRETO et al. (2011) when studying the feeding behavior of native Moxotó and Canindé goats with different diets, but differs from quoted by RIBEIRO et al. (2006), who analyzed the feeding behavior of goats fed ad libitum and under restriction, mentioned that the demand for water was higher (1.94 times), for the animals fed ad libitum, and inferior to the present research. ARAÚJO et al. (2010) reported that among the factors that affect water consumption are: heat, which promotes more effective in increasing water consumption; dry matter intake (RIBEIRO et al., 2006), which has a direct relation with the water consumption; mineral supplementation, which increases the demand especially in pregnant and lactating female; and confinement considering that the stabled animals tend to decrease consumption in relation to those in pasture.

TABLE 4. Mean and coefficients of variation (C.V.) of water search expressed in the number of times by day according to the native goats genotypes under confinement.

\begin{tabular}{lccccccc}
\hline & \multicolumn{3}{c}{ Genotypes } & \multicolumn{3}{c}{ Period (h day $\left.{ }^{-1}\right)$} & C.V. (\%) \\
\cline { 2 - 8 } Activities $\left(\mathrm{n}^{0}\right)$ & Azul & Graúna & Moxotó & $12-20$ & $20-04$ & $04-12$ & \\
\hline Water & 2.95 & 1.99 & 3.50 & 3.56 & 2.75 & 2.40 & 87.21 \\
\hline
\end{tabular}

It is also observed that the goats had a greater demand for water between $12 \mathrm{pm}$ and $8 \mathrm{pm}$, corresponding to the hottest periods of the day, in which occurred high temperatures $\left(33.1^{\circ} \mathrm{C}\right.$ at $3 \mathrm{pm})$, associated with low relative humidity $(37.1 \%$ at $3 \mathrm{pm})$, and the thermolysis most effective when the thermal load on the environment is high is the evaporation, which causes to the animals a 
greater water loss, mainly by perspiration (BRASIL et al., 2000), consequently, to a higher water consumption. According to RIBEIRO et al. (2006), this also occurs due to the habit of these animals to have their eating and ruminating activities during the day, stimulating the demand for water, and at night, due to the processes of digestion, a greater elimination of the food that was not absorbed and the metabolites occurs, most via feces and urine. POMPEU et al. (2009), by analyzing the behavior of sheep, found that they had higher water consumption in the hottest periods of the day.

The mean water consumption exposed to sun and shade and the total water consumption by animals are presented in Table 5. Even with the mean water temperature in the sun above the recommended for all breeds, there was a preference for this water, corresponding to an average consumption of $64.71 \%$ of the total. Between the breeds, the preference for water exposed to the sun was the Azul (71.18\%), followed by Moxotó (65.95\%) and Graúna (57\%).

TABLE 5. Mean water consumption exposed to sun and shade, total water consumption, consumption per unit of metabolic weight (UTM) and dry matter consumption (DM).

\begin{tabular}{|c|c|c|c|c|c|}
\hline \multirow[b]{2}{*}{ Breed } & \multicolumn{4}{|c|}{ Water Consumption by Animals } & \multirow[b]{2}{*}{$\begin{array}{l}\text { DM Consumption } \\
\left(\text { g day }^{-1}\right)\end{array}$} \\
\hline & $\begin{array}{l}\text { Sun water } \\
\left(\mathrm{g} \mathrm{day}^{-1}\right)\end{array}$ & $\begin{array}{l}\text { Shade Water } \\
\left(\mathrm{g} \mathrm{day}^{-1}\right)\end{array}$ & $\begin{array}{c}\text { Total } \\
\text { Consumption } \\
\text { (g/day) }\end{array}$ & $\begin{array}{c}\text { Consumption (UTM) } \\
\mathrm{g} / \mathrm{W}^{0,75}\end{array}$ & \\
\hline Moxotó & $620 \mathrm{bA}$ & $320 \mathrm{bB}$ & $940 \mathrm{~b}$ & $114 a$ & $620 \mathrm{~b}$ \\
\hline Azul & $840 \mathrm{aA}$ & $340 \mathrm{bB}$ & $1.180 \mathrm{a}$ & $143 \mathrm{~b}$ & $570 \mathrm{c}$ \\
\hline Graúna & $780 \mathrm{abA}$ & $570 \mathrm{aB}$ & $1.340 \mathrm{a}$ & $163 \mathrm{~b}$ & $750 \mathrm{a}$ \\
\hline Mean & 750 & 410 & 1.150 & 140 & 650 \\
\hline C.V.\% & 57.1 & 70.3 & 38.2 & 24.0 & 24.0 \\
\hline
\end{tabular}

Means followed by the same lower-case letter in the column and by the same capital letter in the row do not differ by the Tukey test, at $5 \%$ of probability.

This preference for the water exposed to the sun can be explained by the adaptation that native goats had throughout its evolution in semiarid northeastern region (SANTOS et al., 2005; and SILVA et al., 2010), where the temperature is always high, which also raises the temperature of the water, but also highlights the need to establish values of ideal water temperature for goats, especially those bred in arid and semiarid regions, mainly due to the small amount of information available on these animals in these regions (ARAÚJO et al., 2010). ROCHA et al. (2009), comparing the adaptation of Saanen and Azul goats in the Mid North region of Brazil, during the rainy and dry season, concluded that the Azul breed was more adapted to the experimental conditions.

The mean total water consumption was $1,150 \mathrm{~g} \mathrm{day}^{-1}$, corresponding to $6.9 \%$ of the body weight of the animals, and the Moxotó goats ingested less water than other breeds. MISRA \& SINGH (2002), analyzing native breeds in India, have also observed that there is difference in water consumption between the breeds. This consumption was higher than that recommended by the NRC (2007), and this fact can be explained by the high temperature and low relative humidity to which the animals were subjected, especially during the day.

The average weights of the breeds, at the end of the experiment, did not differ significantly from each other $(\mathrm{P}>0.05)$, which was $16.6 \mathrm{~kg} / \mathrm{LW}$, and the dry matter intake differed significantly $(\mathrm{P}<0.05)$ among animals, in which Graúna goats were the ones which consumed the most, followed by Moxotó and Azul. This higher water consumption by Graúna may be due to its darker color, which absorbs more heat, but also by the higher dry matter intake. GONÇALVES et al. (2008), in research with different fodder for sheep, have observed that increased water consumption occurred when the animals consumed greater amount of dry matter.

Comparing the mean consumption of dry matter with the mean water consumption among the breeds, it is observed that the Azul breed was 1.0:2.07, the Graúna breed was 1.0:1.79, and the 
Moxotó breed was 1.0:1.52, with a 1.0:1.77 mean. The values of this research to both Azul and Graúna were higher than the recommended by NRC (2007), which mentions that there must be a relation between dry matter and water consumption, which in this experiment should have a mean of 1.52 liters. ABIOJA et al. (2010) reported that there is a positive correlation between the food and water consumption, and in the present study it may be observed that the Moxotó goats consumed less dry matter and water in relation to other animals.

This high water consumption may also be explained by the type of food provided, which had a roughage: concentrate ratio of 47:53, and a high percentage of energy in the diet increases the water consumption (RIBEIRO et al., 2006 and ARAÚJO et al., 2010), but also to the environment where the animals were housed, subjected to high temperatures and low relative humidity (Table 1). NEIVA et al. (2004), in a study with sheep, in northeastern Brazil, reported that there was an increase in water consumption with the increase of the concentrate level in the diet. VIEIRA et al. (2008) claim that there is a reduction in consumption with the addition of palm forage, which did not occur in the present study, this in function of temperature, humidity and the small amount of palm in the diet.

Another factor that should be highlighted is that with the process of natural selection that native semiarid region goats go through, they tend to consume more water, maximizing their use. A similar situation was reported by ARAÚJO et al. (2009), which works with Moxotó dairy goats in the semiarid region of Paraíba, correlating the dry matter and water consumption, showed that this was 1.0:2.28, superior to the present experiment and the one recommended by the NRC (2007), which can be justified by the animal category, as milk production increases metabolism, thus the water consumption. As for the water consumption per metabolic weight, RIBEIRO (1997) mentions that goats should consume $146 \mathrm{~g}$ of water per unit of metabolic weight for maintenance, an amount that is similar to the mean consumed by the Graúna and Azul goats, but higher than Moxotó. ARAÚJO et al. (2009), in studies with dairy goats in the semiarid region of Paraíba, mentioned water consumption values per unit of metabolic size ranging from 112.62 to 120.31 , and therefore inferior to Azul and Graúna.

\section{CONCLUSIONS}

For all breeds, there was a preference for water exposed to the sun, corresponding to a mean consumption of $64.71 \%$ of the total. Among the breeds, the preference for water exposed to the sun was the Azul (71.18\%), followed by Moxotó (65.95\%) and Graúna (57\%). The lower dry matter intake also led to lower water consumption. The preference for water consumption occurred during the day and the mean water consumption was $1.150 \mathrm{gr} /$ day, corresponding to $6.9 \%$ of the animal weight.

\section{ACKNOWLEDGMENTS}

We thank CNPq for financing this research.

\section{REFERENCES}

ABIOJA, M.O.; OSINOWO, O.A.; ADEBAMBO, O.A.; BELLO, N.J.; ABIONA, J.A. Water restriction in goats during hot-dry season in the humid tropics: feed intake and weight gain. Archivos de Zootecnia, Córdoba, v.59, n.226, p.195-203, 2010.

ALVES, K.S.; CARVALHO, F.F. R. de.; BATISTA, A.M.V. Composição corporal e exigências de energia para ganho de peso de caprinos Moxotó em crescimento. Revista Brasileira de Zootecnia, Viçosa-MG, v.37, n.10, p.1853-1859, 2008.

AOAC - ASSOCIATION OF OFFICIAL ANALYTICAL CHEMISTS. Official methods of analysis of the association analytical chemists. $18^{\text {th }}$ ed. Maryland: AOAC, 2005. 
ARAUJO, G.G.L.; VOLTOLINI, T.V.; CHIZZOTTI, M.L.; TURCO, S.H.N.; CARVALHO, F.F.R. de. Water and small ruminant production. Revista Brasileira de Zootecnia, Viçosa-MG, v.39, p.326-336, 2010 (suplemento especial).

ARAÚJO, M.J.; MEDEIROS, A.N.; CARVALHO, F.F.R. de; SILVA, D.S. da.; CHAGAS, E.C.O. Consumo e digestibilidade dos nutrientes em cabras Moxotó recebendo dietas com diferentes níveis de feno de maniçoba. Revista Brasileira de Zootecnia, Viçosa-MG, v.38, n.6, p.1088-1095, 2009.

BAÊTA, F;C.; SOUZA, C.M. Ambiência em edificações rurais: conforto animal. 2.ed. Viçosa: Ed. UFV, 2010. 269 p.

BARRETO, L.M.G.; MEDEIROS, A.N. de; BATISTA, A.M.V.; FURTADO, D.A.; ARAÚJO, G.G.L.; LISBOA, A.C.C.; PAULO, J.L.A.; SOUZA, C.M.S. Comportamento ingestivo de caprinos das raças Moxotó e Canindé em confinamento recebendo dois níveis de energia na dieta. Revista Brasileira de Zootecnia, Viçosa-MG, v.40, n.4, p.834-842, 2011

BRASIL, L.H.A.; WECHESLER, F.S.; BACCARI JUNIOR, F.; GONÇALVES, H.C.; BONASSI, I.A. Efeitos do estresse térmico sobre a produção, composição química do leite e respostas termorregulatórias de cabras da raça Alpina. Revista Brasileira de Zootecnia, Viçosa-MG, v.29, n.6. p.1632-1641, 2000.

CALE, J.R.C.; SÁNCHEZ, E.C. Necessidades de agua. In: Zootecnia: Bases de production animal. Tomo II - Reproduccion y alimentacion. Madrid: Ed. Mundi-Prensa, 1995, 293 p.

DIAS, A.M.A.; BATISTA, A. M.V.; MAIA, M. de M. D.; CARVALHO, F.F.R. de; GUIM, A.; SILVA, A. Composição tecidual, química e de ácidos graxos presentes em pernas de caprinos alimentados com dieta rica em farelo grosso de trigo. Revista Brasileira de Ciências Agrárias, Recife, v.3, n.1, p.79-84, 2008.

FURTADO, D.A.; GOMES, C.A.V.; MEDEIROS, A.N.; PIMENTA FILHO, E.C.; LIMA JUNIOR, V. Effects of thermal environment and supplementation levels on the physiological parameters of moxotó goats in confined and semi-confined rising systems. Engenharia Agrícola, Jaboticabal, v.28, n.3, p.396-405, 2008.

GONÇALVES, G. da S.; OLIVEIRA, G.J.C.; JAEGER, S.M.P.L.; OLIVEIRA, R.L.; CAMPOS, J.O.; RESENDE, L.S. Desempenho de cordeiros alimentados com dietas contendo sal forrageiro de espécies vegetais xerófitas. Revista Brasileira de Zootecnia, Viçosa-MG, v.37, n.12, p.2185-2190, 2008.

MACARI, M.; FURLAN, R.L. Ambiência na produção de aves em clima tropical. In: SILVA, I.J.O. Ambiência na produção de aves em clima tropical. Jaboticabal: SBEA, 2001. p.31-87.

MATTOS, C.W.; CARVALHO, F.F.R.; JÚNIOR DUTRA, W.M.; VERAS, A.S.C.; BATISTA, A.M.V.; ALVES, K.S.; RIBEIRO, V.L.; SILVA, M.J.M.S.; MEDEIROS, G.R.; VASCONCELOS, R.M.J.; ARAÚJO, A.O.; MIRANDA, S.B.M. Características de carcaça e dos componentes nãocarcaça de cabritos Moxotó e Canindé submetidos a dois níveis de alimentação. Revista Brasileira de Zootecnia, Viçosa-MG, v.35, n.5, p.2125-2134, 2006.

MISRA, A.K.; SINGH, K. Effect of water deprivation on dry matter intake, nutriente utilization and metabolic water production in goats under semi-árid zone of India. Small Ruminant Research, Amsterdam, v.46, p. 159-165, 2002.

NEIVA, J.N.M.; TEIXEIRA, M.; TURCO, S.H.N.; OLIVEIRA, S.M.P. de; MOURA, A.A.A.N. Efeito do estresse climático sobre os parâmetros produtivos e fisiológicos de ovinos Santa Inês mantidos em confinamento na região litorânea do Nordeste do Brasil. Revista Brasileira de Zootecnia, Viçosa-MG, v.33, n.3, p.668-678, 2004.

NRC - NATIONAL RESEARCH COUNCIL. Nutrient requirements of small ruminant: sheep, goats, cervids and new world camelids. Washington, 2007. 384 p. 
POMPEU, R.C.F.F.; ROGÉRIO, M.C.P.; CANDIDO, M.J.D.; NEIVA, J.N.M.; GUERRA, J.L.L.; GONÇALVES, J.S. Comportamento de ovinos em capim-tanzânia sob lotação rotativa com quatro níveis de suplementação concentrada. Revista Brasileira de Zootecnia, Viçosa-MG, v.38, n.2, p.374-383, 2009.

RIBEIRO, S.D.A. Caprinocultura: Criação racional de caprinos. São Paulo: Nobel, 1997. 317 p.

RIBEIRO, V.L.; BATISTA, A.M.V.; CARVALHO, F.F.R.; AZEVEDO, M.; MATTOS, C.W.; ALVES, K.S. Comportamento ingestivo de caprinos Moxotó e Canindé submetidos à alimentação à vontade e restrita. Acta Scientiarum. Animal Sciences, Maringá, v.28, n.3, p.331-337, 2006.

RIBEIRO, V.L.; BATISTA, A.M.V.; CARVALHO, F.F.R.; SILVA, M.J.M.S.; MATTOS, C.W. ALVES, K.S. Seletividade e Composição da dieta ingerida por caprinos recebendo alimentação à vontade e restrita. Revista Brasileira de Ciências Agrárias, Recife, v.4, n.1, p.91-94, 2009.

ROCHA, R.R.C.; COSTA, A.P.R.; AZEVEDO, D.M.M.R.; NASCIMENTO, H.T.S. do; CARDOSO, F.S.; MURATORI, M.C.S.; LOPES, J.B. Adaptabilidade climática de caprinos Saanen e Azul no Meio-Norte do Brasil. Arquivo Brasileiro de Medicina Veterinária e Zootecnia, Belo Horizonte, v.61, n.5, p.1165-1172, 2009.

SANTOS, F.C.B. dos; SOUZA. B.B.; ALFARO, C.E.P.; CEZAR, M.F.; PIMENTA FILHO, E.C.; ACOSTA, A.A.A.; SANTOS, J.R.S. Adaptabilidade de caprinos exóticos e naturalizados ao clima semi-árido do Nordeste brasileiro. Ciência e Agrotecnologia, v.29, n.1, p.142-149, 2005.

SAS - STATISTICAL ANALYSIS SYSTEM INSTITUTE. General Linear Model: 8,2. Cary: SAS Institute, 2000.

SILVA, E.M.N.; SOUZA, B.B.; SOUSA, O.B.; SILVA, G.A.; FREITAS, M.M.S.de. Avaliação da adaptabilidade de caprinos ao semiárido através de parâmetros fisiológicos e estruturas do tegumento. Revista Caatinga, Mossoró, v.23, n.2, p.142-148, 2010.

VIEIRA, E.L.; BATISTA, A.M.V.; MUSTAFA, A.F.; ARAÚJO, R.F.S.; SOARES, P.C.; ORTOLANE, E.F.; MORI, C.K. Effects of feeding high levels of cactus (Opuntia fícus-indica Mill) cladodes on unirnary and eletrolyte excretions in goat. Livestock Production Science, Amsterdam, v.114, p.159-165, 2008. 